\title{
Parthenolide production in cell suspension culture of feverfew
}

\author{
Farzaneh Pourianezhad ${ }^{1}$, Hassan Rahnama ${ }^{2}$, Amir Mousavi ${ }^{3 *}$, Mahmood Khosrowshahli ${ }^{4}$ \\ and Sudabeh Mafakheri ${ }^{5}$
}

\begin{abstract}
Feverfew (Tanacetum parthenium) is one of the most important medicinal plants with different pharmacologic properties, such as anti-inflammatory, cardiotonic, antitumor and antiangiogenic activities. Parthenolide (PN) is a main bioactive molecule in feverfew which belongs to sesquiterpene lactone compounds. Currently, the plant cell suspension has been used as a useful method to produce secondary metabolites (SMs) components. Meanwhile, the elicitor application is an effective strategy to induce the production of SMs in plants. The present study was conducted as two different experiments in cell suspension of feverfew. In the first experiment, the effects of explant (shoot and root), hormone (TDZ + NAA and TDZ + 2. 4-D) on cell dry weight for one month were investigated. In the second experiment, the effect of elicitor (namely, MJ, YE and Ag+) and the hormones after 24,48 and $72 \mathrm{~h}$ on PN content was assessed. The result of the first experiment revealed that the simple effects and the interaction of hormone $x$ explant were significant $(P<0.01)$ for cell dry weight. Growth rate analysis showed that shoot-derived cell suspension in $1 \mathrm{mg} \mathrm{L}{ }^{-1} \mathrm{NAA}+0.5 \mathrm{mg} \mathrm{L}^{-1} \mathrm{TDZ}$ treatment had the highest amount of cell dry weight 14 days after the culture. According to the second experiment, the highest PN content was obtained in cell suspension containing $0.5 \mathrm{mg} \mathrm{L}^{-1}$ 2, 4-D $+0.1 \mathrm{mg} \mathrm{L}^{-1} \mathrm{TDZ}$ with application of the YE + MJ elicitor after $48 \mathrm{~h}$. The cell suspension treatment with each of the elicitors had a positive effect on the PN production. In conclusion, the application of combined elicitors in feverfew cell suspension culture can be used as an efficient tool for large-scale PN production.
\end{abstract}

Keywords: Elicitors, Feverfew (Tanacetum parthenium), Cell suspension culture, Parthenolide

\section{Introduction}

Feverfew (Tanacetum parthenium) is one of the most important medicinal plants with different pharmacological and therapeutic properties (Pourianezhad et al. 2016). It is a perennial plant of Asteraceae family. The plant is native to Kazakhstan, Central Asia and Mediterranean region, but it can be found in different parts of Europe, Asia and America (Arabasi and Bayram 2005; Farzaneh et al. 2002). The plant has been used to treat a wide range of diseases such as menstrual disorders, toothache, migraine, asthma, fever, stomach ache, arthritis, insect bites and helminthiasis (Maggi 2019; Sadat-Hosseini et al. 2017). Secondary metabolites (SMs) have complex

\footnotetext{
*Correspondence: m-amir@nigeb.ac.ir

${ }^{3}$ Department of Plant Molecular Biotechnology, National Institute of Genetic Engineering and Biotechnology (NIGEB), Tehran, Iran Full list of author information is available at the end of the article
}

structures to be manufactured by chemical synthesis and thus frequently extracted from naturally grown or cultivated plants (Deepthi and Satheeshkumar 2016). SMs are produced by different medicinal plants under biotic and abiotic stresses (Ebrahimi et al. 2012; Farajpour et al. 2017). Parthenolide (PN) is one of the major bioactive components of Feverfew. It is well known to have potential anti-inflammatory properties (Zhang et al. 2004). PN, a sesquiterpene lactone, is mostly produced by the mevalonate (MVA) pathway (Fig. 1). In this pathway, acetylCoA is converted to isopentenyl pyrophosphate (IPP) in six steps. Then, two IPPs and one dimethylallyl pyrophosphate (DMAPP) are transformed to farnesyl diphosphate (FPP), which is precursor for all sesquiterpenes, through farnesyl diphosphate synthase (FPS). Afterward, sesquiterpene synthase converted FPP to sesquiterpenes, which are further modified by oxidation reactions using cytochrome P450 enzymes. PN has a germacranolide 


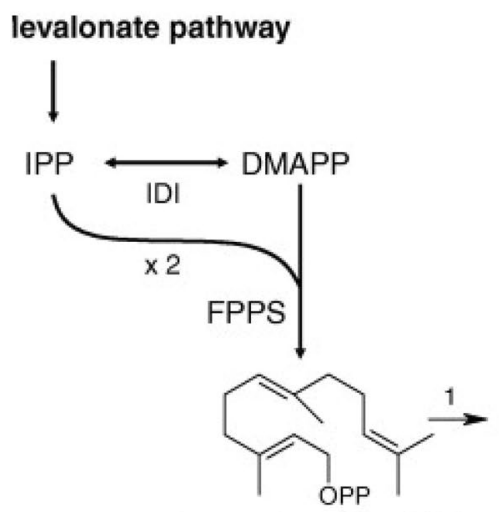

Farnesyl diphosphate (FPP)

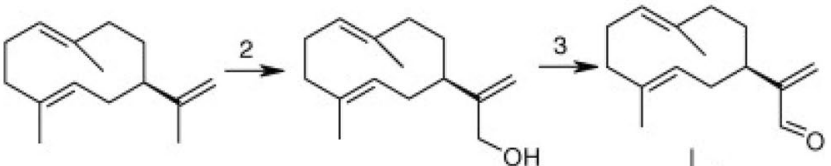

(+)-germacrene A

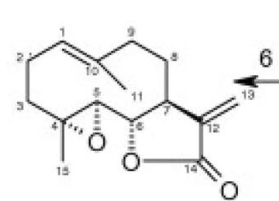

Parthenolide

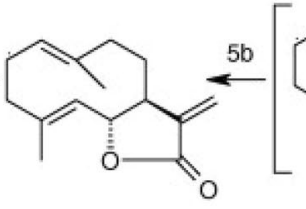

(+)-costunolide

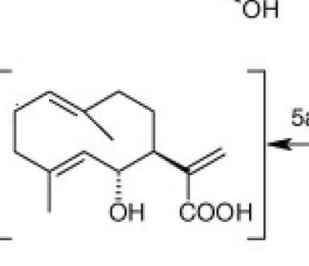<smiles>C=C(C(=O)O)C1CC/C2=C/CC(C(C)C)C(C)=CCC2C1</smiles>

germacranoic acid
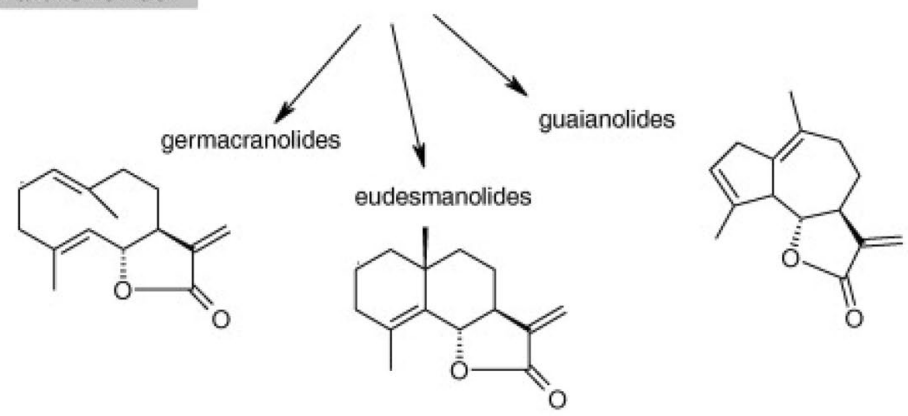

Fig. 1 Presumed biosynthetic pathway of parthenolide; step 1 is catalyzed by germacrene A synthase; steps 2, 3 and 4 are catalyzed by germacrene A oxidase; step 5a, 5b, costunolide synthase; and step 6, costunolide epoxidase/parthenolide synthase (Majdi et al. 2011)

backbone structure. Germacrene A oxidation to germacranoic acid in feverfew is usually accomplished by a similar P450 monooxygenase (Majdi et al. 2011; van Klink et al. 2003). Transcription level of SMs-related genes determines the biosynthesis and accumulation of SMs in plants, which can occur in different growth phases and places such as organs, tissues (De Kraker et al. 2002). Different parts of feverfew had different amounts of PN, so that the maximum PN content was detected in flower head and leaves ( 1.38 and $0.95 \%$, respectively), while the PN contents in stalks and roots were 0.08 and $0.01 \%$, respectively (Heptinstall et al. 1992). Currently, the plant cell culture has been used as a useful method for SMs components production (Zhong 2001). It is a promising alternative approach instead of traditional methods (Yue et al. 2016). High SM production is important for the commercial utilization of cell suspension cultures. There are many reports about increasing the SM production in cell cultures via some culture parameters such as elicitation, hormone, medium culture and precursor feeding (Khan et al. 2018).

The mechanism of induction of SMs production by elicitors is same as the biotic/abiotic stresses. Elicitors activate a range of defense mechanisms, including the production and accumulation of an array of plantdefensive SMs in plants or cell suspension cultures (Zhao et al. 2005). There are several different components that can completely substitute for biotic or abiotic elicitors in the elicitation effect. Moreover, several binding sites for protein or peptides elicitors were also characterized in different plants (Zhai et al. 2017). Elicitors were used in many studies as an enhanced biomass production in different plants in vitro culture such as Ophiorrhiza mungos (Deepthi and Satheeshkumar 2016), Silybum marianum (Gabr et al. 2016), Glycyrrhiza uralensis (Wang et al. 2017), Eruca sativa (Kastell et al. 2018), Isatis tinctoria (Gai et al. 2019) and Centella asiatica (Gupta and Chaturvedi 2019). There are many elicitors such as 
$N, N^{\prime}$-dicyclohexylcarbodiimide and the derivatives of methyl jasmonate, salicylate and 2,6-dichloroisonicotinate as novel and powerful inducers for plant secondary metabolism (Huang et al. 2013; Qian et al. 2006a, b). However, among them, methyl jasmonate and salicylate elicitors were most used in different medicinal plants (Gai et al. 2019; Hao et al. 2015; Krzyzanowska et al. 2012; Lee-Parsons et al. 2004; Majdi et al. 2015). Elicitors such as MJ, SA, yeast extract (YE) and $\mathrm{Ag}^{+}$could be an effective tool to increase PN production because they are not destructive for plant tissues related to terpene accumulation (Majdi et al. 2011). Leaves of T. parthenium were elicited using methyl jasmonate (MJ) and salicylic acid (SA), and both elicitors activated PN biosynthesis (Majdi et al. 2015). We have previously investigated the effects of various elicitors including yeast extract (YE) (2.5 $\left.\mathrm{mg} \mathrm{L}^{-1}\right)$, methyl jasmonate (MJ) $(100 \mu \mathrm{M}), \mathrm{Ag}^{+}(100 \mu \mathrm{M})$, $\mathrm{YE}+\mathrm{MJ}, \mathrm{Ag}^{+}+\mathrm{MJ}, \mathrm{YE}+\mathrm{Ag}^{+}$and $\mathrm{YE}+\mathrm{MJ}+\mathrm{Ag}^{+}$on the production of $\mathrm{PN}$ in feverfew hairy root culture (Pourianezhad et al. 2019). We obtained the highest values of PN contents by application of different combined elicitors. The aims of the current study were to (1) determine the appropriate time for applying the elicitors in suspension culture and (2) investigate the effect of elicitors and their combinations, namely $\mathrm{MJ}, \mathrm{YE}, \mathrm{Ag}^{+}, \mathrm{MJ}+\mathrm{YE}, \mathrm{MJ}+\mathrm{Ag}^{+}$, $\mathrm{YE}+\mathrm{Ag}^{+}$and $\mathrm{MJ}+\mathrm{YE}+\mathrm{Ag}^{+}$, on $\mathrm{PN}$ content in T. parthenium suspension culture.

\section{Materials and methods}

\section{Plant material and callus induction}

Seeds were obtained from Isfahan Pakan Bazr Company and surface-sterilized by soaking in $70 \%$ ethanol for $30 \mathrm{~s}$ and immersing in $2 \%$ sodium hypochlorite for $5 \mathrm{~min}$. Afterward, the seeds were washed three times with sterile distilled water (SDW) and germinated on $1 / 4$ strength MS medium containing 3 and $0.8 \%(\mathrm{w} / \mathrm{v})$ sucrose and agar, respectively, at pH 5.7 (Murashige and Skoog 1962). The cultures were kept in an incubator at $25{ }^{\circ} \mathrm{C}$ with 16:8-h long-day (LD) photoperiod and white fluorescent tubes (ca. $40 \mu \mathrm{mol} \mathrm{m}{ }^{-2} \mathrm{~s}^{-1}$ ) on $1 / 2$ strength MS medium. In order to induce the callus formation, the sterilized explants (leaf and stem) were cut into 5 -mm sections and placed on $1 / 2$ strength MS solid medium containing different concentrations of TDZ $\left(0,0.1\right.$ and $\left.0.5 \mathrm{mg} \mathrm{L}^{-1}\right)$, NAA $\left(0,0.5,1\right.$ and $\left.2 \mathrm{mg} \mathrm{L}^{-1}\right)$ and 2,4-D $\left(0,0.5,1\right.$ and $\left.2 \mathrm{mg} \mathrm{L}^{-1}\right)$ supplemented with $30 \mathrm{~g} \mathrm{~L}^{-1}$ sucrose. After four weeks, the induced callus was detached from explants and separately cultured until being used in cell suspension culture.

\section{Cell suspension culture and growth curve analysis}

According to the results of callus induction experiments (data not shown), the two best hormonal treatments including $1 \mathrm{mg} \mathrm{L}^{-1} \mathrm{NAA}$ and $0.5 \mathrm{mg} \mathrm{L}^{-1} \mathrm{TDZ}$, and
$0.5 \mathrm{mg} \mathrm{L}^{-1} 2,4-\mathrm{D}$ and $1 \mathrm{mg} \mathrm{L}^{-1} \mathrm{TDZ}$ were selected for cell suspension culture. To this aim, about $2 \mathrm{~g}$ of selected fresh callus was transferred to a 500-mL Erlenmeyer flask containing $100 \mathrm{~mL}$ of culture medium and incubated at room temperature $\left(25^{\circ} \mathrm{C}\right)$ on a rotary shaker $(110 \mathrm{rpm})$ in darkness. Subculture was performed at 2-week interval by adding $30 \mathrm{~mL}$ of each suspension culture to an Erlenmeyer flask containing $70 \mathrm{~mL}$ of fresh culture medium.

The growth of the cells in suspension cultures was studied by measurement of cell dry weight for 30 days. Five milliliters of suspension cultures was added to 100 $\mathrm{mL}$ Erlenmeyer flask containing $20 \mathrm{~mL}$ of $1 / 2$ strength MS liquid medium supplemented with the same hormonal concentrations, and the cultures were incubated on a rotary shaker at $90 \mathrm{rpm}$. At every two days, $1.5 \mathrm{~mL}$ of suspension cultures was filtered through Whatman filter paper and dried at $60^{\circ} \mathrm{C}$ for $24 \mathrm{~h}$ and cell dry weights were measured.

\section{Elicitors preparation and application}

In the present study, three elicitors and their combinations were used. The elicitors included yeast extract (YE, $2.5 \mathrm{mg} \mathrm{L}^{-1}$ ), methyl jasmonate (MJ, $\left.0.5 \mathrm{mg} \mathrm{L}^{-1}\right), \mathrm{AgNO}_{3}$ $\left(\mathrm{Ag}^{+}, 0.5 \mathrm{mg} \mathrm{L}^{-1}\right), \mathrm{YE}+\mathrm{MJ}, \mathrm{Ag}^{+}+\mathrm{MJ}, \mathrm{YE}+\mathrm{Ag}^{+}$and $\mathrm{YE}+\mathrm{MJ}+\mathrm{Ag}^{+}$. The elicitors were added to the suspension cultures at day 14. After 24, 48 and $72 \mathrm{~h}$ of elicitor application, the cell biomass was frozen and lyophilized for PN content measurement. YE and AgNO3 were dissolved in SDW and methyl jasmonate in $70 \%(\mathrm{v} / \mathrm{v})$ ethanol. Membrane filter $(0.2 \mu \mathrm{m})$ was used to sterilize the solutions and then they were stored at $-20^{\circ} \mathrm{C}$.

\section{PN measurement}

Lyophilized cell biomass was powdered in liquid nitrogen using a chilled mortar and pestle. The PN content was measured according to a protocol described by Jeong et al. (Jeong et al. 2005). All details about the used method can be found in our previous report (Pourianezhad et al. 2019).

\section{Statistical analysis}

In the present study, two different experiments were carried out. The first experiment was a completely randomized factorial design to study the effects of hormone, explant and time on cell dry weight. In the second one, the effects of hormone, elicitor and time on PN content were evaluated. The ANOVA and LSD tests were applied for statistical assessments using Statistical Analysis System (SAS, v9.1 for Windows, SAS Institute Cary, NC). 


\section{Results and discussion}

\section{Effects of hormone and explant on cell dry weight}

According to our previous study, different hormonal treatments were used for callus induction in feverfew. Based on the results (data not shown), two hormonal treatments including $1 \mathrm{mg} \mathrm{L}^{-1} \mathrm{NAA}+0.5 \mathrm{mg} \mathrm{L}^{-1} \mathrm{TDZ}$ and $0.5 \mathrm{mg} \mathrm{L}^{-1} 2,4-\mathrm{D}+0.1 \mathrm{mg} \mathrm{L}^{-1} \mathrm{TDZ}$ were selected for cell suspension culture. The hormonal treatments were applied to shoot- and root-derived cell suspension cultures, and every two days, cell dry weight was measured for one month. ANOVA revealed that the simple effects and the interaction of hormone $\times$ explant were significant $(P<0.01)$ for cell dry weight in feverfew cell suspension culture, while other interactions were nonsignificant (Table 1). Based on the mean comparison results, the highest amount of cell dry weight was obtained from shoot-derived cell suspension in $1 \mathrm{mg} \mathrm{L}^{-1}$ $\mathrm{NAA}+0.5 \mathrm{mg} \mathrm{L}^{-1}$ TDZ treatment, which was significantly different from the other treatments. No significant differences were observed among the other treatments (Fig. 2). Modarres et al. (2018) established a cell suspension culture of Salvia leriifolia to induce the bio-production of phenolic acids. They obtained the highest rate of callus induction (100\%) and callus dry weight (0.38 g) in medium containing $5 \mathrm{mg} \mathrm{L}^{-1} \mathrm{NAA}$ and 6-benzylaminopurine. Studies have revealed that the plant growth and secondary metabolite production were affected by the auxin and cytokinin types and their concentrations (Rao and Ravishankar 2002). Time-course analysis of cell growth rate revealed a lag period of 10 days in shootderived cell suspension in TDZ + NAA treatment. A logarithmic growth from days 4-14 was detected and then declined. The other treatments showed no logarithmic

Table 1 Analysis of variance of the effect of hormone, explant/elicitor and time on two measured characters of feverfew cell suspension culture

\begin{tabular}{|c|c|c|c|c|c|}
\hline S.O.V (CRD) & $d f$ & $\begin{array}{l}\text { Mean square } \\
\text { Cell dry } \\
\text { weight }\end{array}$ & S.O.V (RCBD) & $d f$ & $\begin{array}{l}\text { Mean square } \\
\text { Parthenolide }\end{array}$ \\
\hline Hormones $(H)$ & 1 & $6.84^{* *}$ & Hormones $(H)$ & 1 & $0.0026^{* *}$ \\
\hline- & - & - & Block & 2 & $0.0007^{* *}$ \\
\hline Explant (E) & 1 & $15.2^{* *}$ & Elicitor $(E)$ & 7 & $0.0009^{* *}$ \\
\hline Time $(T)$ & 14 & $0.375^{* *}$ & Time $(T)$ & 2 & $0.005^{* *}$ \\
\hline$T^{*} H$ & 14 & $0.108^{\text {ns }}$ & $H^{*} T$ & 2 & $0.002^{* *}$ \\
\hline$H^{*} E$ & 1 & $1.12^{* *}$ & $H^{*} E$ & 7 & $0.0009^{* *}$ \\
\hline$E^{*} T$ & 14 & $0.077^{\text {ns }}$ & $T^{*} E$ & 14 & $0.0006^{* *}$ \\
\hline$T^{*} E^{*} H$ & 14 & $0.068^{\text {ns }}$ & $T^{*} E^{*} H$ & 14 & $0.0003^{* *}$ \\
\hline Error & 60 & 0.091 & Error & 94 & 0.00002 \\
\hline C.V & - & 20.44 & C.V & - & 28.39 \\
\hline
\end{tabular}

S.O.V, source of variations; $d f$, degree of freedom; CRD, completely randomized design; RCBD, randomized complete block design; ns, not significant

**Significantly different $(P \leq 0.01)$

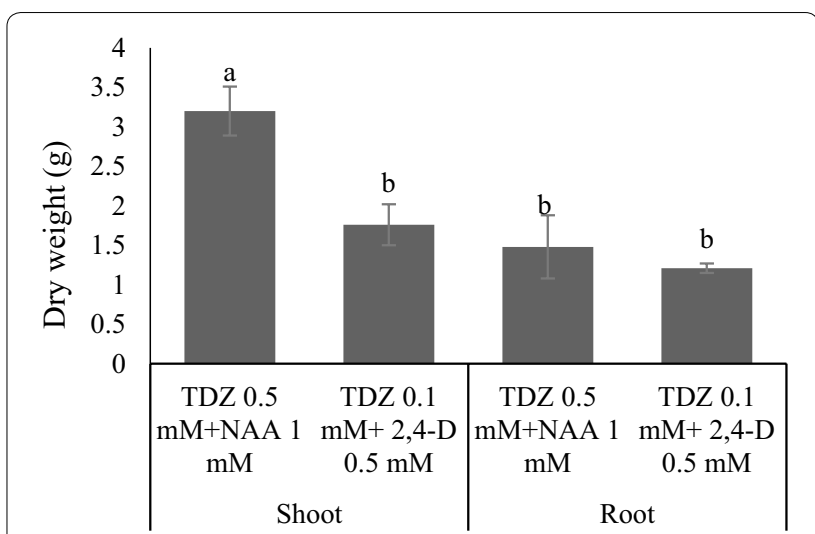

Fig. 2 Effect of hormone and explant on cell dry weight (g) of feverfew cell suspension culture. Means with different letters were significantly different according to the LSD test

phase, and therefore, the best time for applying the elicitors was selected based on this treatment. Furthermore, growth curve analysis showed that shoot-derived cell suspension in TDZ + NAA treatment had the highest amount of cell DW at day 14 (Fig. 3).

\section{Effects of elicitors on PN production}

The elicitors were applied to cell suspension 14 days after culture. After 24, 48 and $72 \mathrm{~h}$ of elicitor application, their effects on PN content were investigated. ANOVA showed that the main effects and their interactions were significant $(P<0.01)$ (Table 1$)$. According to Wickens and Keppel (2004), when the interaction of three factors was significant, less attention is paid to the main effects and we should focus on the interaction effect. Therefore, in the present study, we have focused on the interaction of the three studied factors. The maximum PN production $\left(0.066 \mathrm{mg} \mathrm{g}^{-1} \mathrm{DW}\right)$ was observed in $0.5 \mathrm{mg} \mathrm{L}^{-1} 2,4-\mathrm{D}+0.1 \mathrm{mg} \mathrm{L}^{-1} \mathrm{TDZ}$ treated by $\mathrm{YE}+\mathrm{MJ}$ after $48 \mathrm{~h}$, followed by the same treatment after $24 \mathrm{~h}\left(0.060 \mathrm{mg} \mathrm{g}^{-1} \mathrm{DW}\right)$. Meanwhile, the minimum PN production was observed in control treatment (Fig. 4). According to Fig. 4, all applied elicitors significantly increased the PN production compared to the control treatment. In addition, the result showed that the highest PN content was achieved $48 \mathrm{~h}$ after elicitor application compared to the other times. PN is one of the most imperative sesquiterpene lactones of bioactive compounds in feverfew. The PN biosynthesis regulation process by elicitors is still unknown, while its production is highly genotype dependent (Stojakowska and Kisiel 1997). Methyl jasmonate and salicylic acid stimulate the biosynthesis of many secondary metabolites such as sesquiterpenes, phenols and indole alkaloids (Matkowski 2008; Yu et al. 2006). YE, $\mathrm{AgNO}_{3}$ 


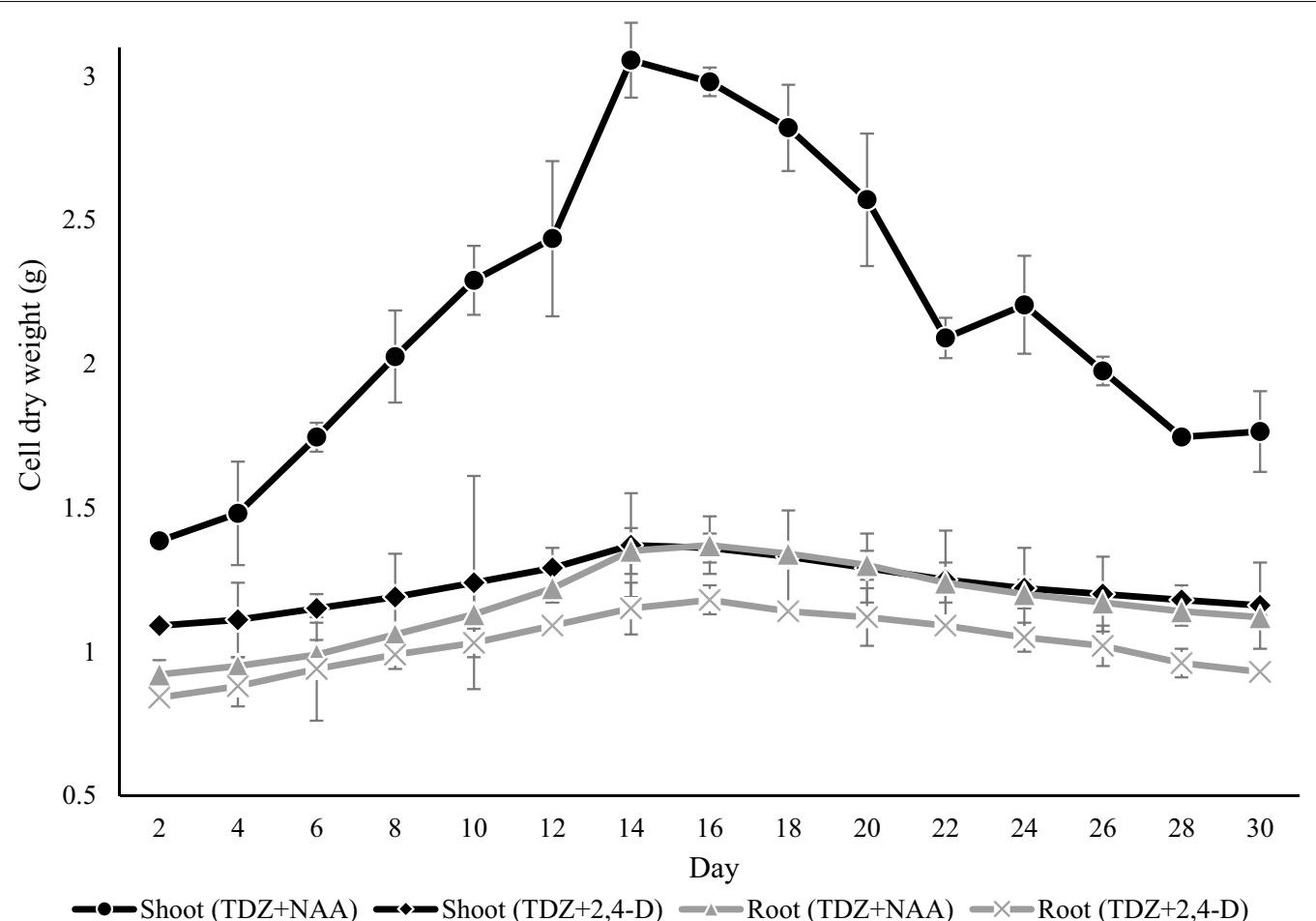

Fig. 3 Time-course analysis of growth rate in cell suspension cultures of T. parthenium in 30-day period

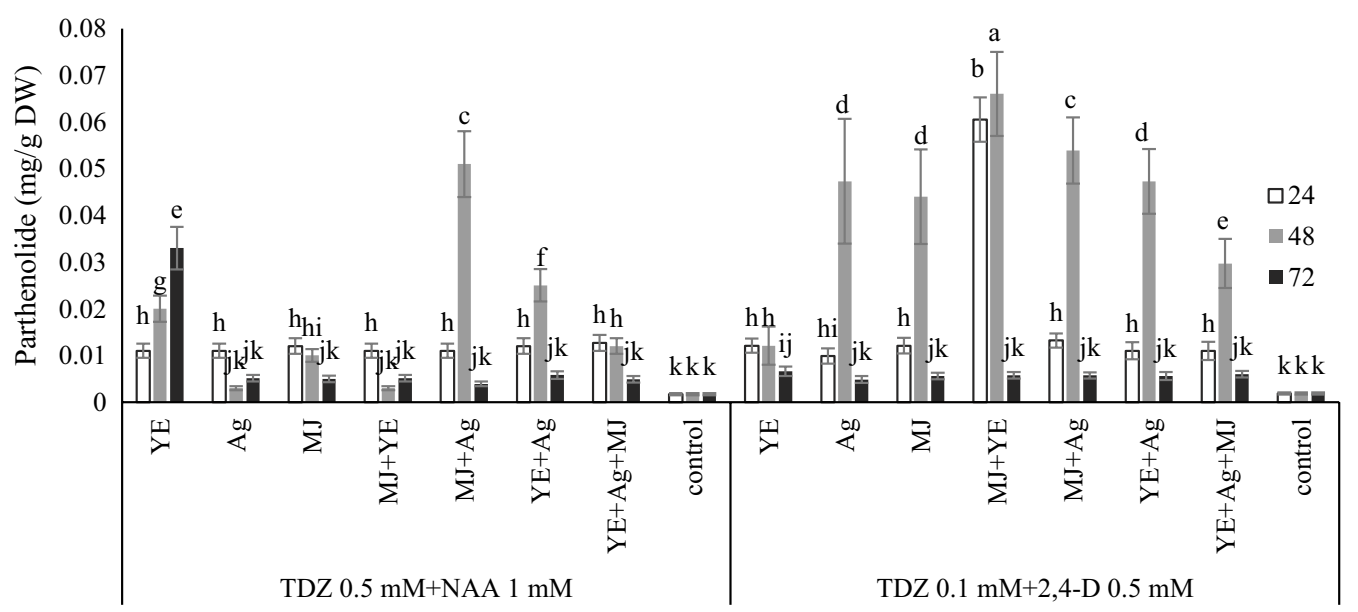

Fig. 4 Effect of hormonal combination, elicitors on parthenolide production in feverfew cell suspension culture after 24,48 and $72 \mathrm{~h}$ of elicitor application. Means with different letters were significantly different according to the LSD test

and MJ elicitors influenced dry weight and secondary metabolites production in various plant species such as Ophiorrhiza mungos, Mentha piperita and Hypericum perforatum (Deepthi and Satheeshkumar 2016; Krzyzanowska et al. 2012; Wang et al. 2015). According to the results, combined elicitors were more useful for PN production. In our previous study, the effects of YE, MJ, Ag elicitors and their combinations on $\mathrm{PN}$ production in feverfew hairy root culture were explored (Pourianezhad et al. 2019). The results of the study showed that the highest PN content was achieved after application of $\mathrm{YE}$ and $\mathrm{MJ}$ combined elicitors. In the present and our previous studies, the best treatment for PN production was YE and MJ combined elicitors; however, the PN content in the cell suspension culture was more than hairy root culture. The reason behind the more 
positive effect of combined elicitors on PN production compared to the separate elicitor application is not yet clear. Whatever it is, the application of combined elicitors can be more useful to the production of parthenolide than separately applied elicitors, which may be due to the interactions between different physiological processes (Zhao et al. 2001).

\section{Conclusion}

We successfully established a cell suspension culture in feverfew for the PN production. The highest amount of cell dry weight was obtained from shoot-derived cell suspension in $1 \mathrm{mg} \mathrm{L}^{-1} \mathrm{NAA}+0.5 \mathrm{mg} \mathrm{L}^{-1} \mathrm{TDZ}$ treatment. Furthermore, the result showed that the highest PN content was obtained in cell suspension containing $0.5 \mathrm{mg} \mathrm{L}^{-1} 2,4-\mathrm{D}+0.1 \mathrm{mg} \mathrm{L}^{-1} \mathrm{TDZ}$ with application of the $\mathrm{YE}+\mathrm{MJ}$ elicitor after $48 \mathrm{~h}$. The cell suspension treatment with each of the elicitors had a positive effect on the $\mathrm{PN}$ production. In conclusion, the application of combined elicitors in cell suspension culture of feverfew can be used as an efficient tool to increase the PN production.

\begin{abstract}
Abbreviations
PN: parthenolide; YE: yeast extract; MJ: methyl jasmonate; SM: secondary metabolites; HPLC: high-performance liquid chromatography; SA: salicylic acid; LSD: least significant difference; ANOVA: analysis of variances.
\end{abstract}

\section{Acknowledgements}

Not applicable.

\section{Authors' contributions}

$\mathrm{HR}$ and $\mathrm{AM}$ conceived and designed the research. FP conducted experiments and wrote the manuscript. MK and SM were involved in results elaboration and discussion, and critical reading of the manuscript. All authors read and approved the final manuscript.

\section{Funding}

Not applicable.

\section{Availability of data and materials}

All data generated or analyzed during this study are included in this article.

Ethics approval and consent to participate

All authors have read and agreed the ethics for publishing the manuscript.

\section{Consent for publication}

All authors approved the consent for publishing the manuscript to bioresources and bioprocessing.

\section{Competing interests}

The authors declare that they have no competing interests.

\footnotetext{
Author details

${ }^{1}$ Department of Horticultural Sciences, Science and Research Branch, Islamic Azad University, Tehran, Iran. ${ }^{2}$ Agricultural Research Education and Extension Organization (AREEO), Agricultural Biotechnology Research Institute of Iran (ABRII), Karaj, Iran. ${ }^{3}$ Department of Plant Molecular Biotechnology, National Institute of Genetic Engineering and Biotechnology (NIGEB), Tehran, Iran.

${ }^{4}$ Department of Biotechnology, Science and Research Branch, Islamic Azad University, Tehran, Iran. ${ }^{5}$ Department of Technical and Engineering, Imam Khomeini International University, Qazvin, Iran.
}

Received: 24 April 2019 Accepted: 19 June 2019

Published online: 03 July 2019

\section{References}

Arabasi D, Bayram E (2005) The effect of nitrogen fertilization and different plant densities on some agronomic and technologic characteristic of (Tanacetum parthenium L.). Essent Oil Res 7:203-205

De Kraker J-W, Franssen MC, Joerink M, De Groot A, Bouwmeester HJ (2002) Biosynthesis of costunolide, dihydrocostunolide, and leucodin. Demonstration of cytochrome P450-catalyzed formation of the lactone ring present in sesquiterpene lactones of chicory. Plant Physiol 129:257-268

Deepthi S, Satheeshkumar K (2016) Enhanced camptothecin production induced by elicitors in the cell suspension cultures of Ophiorrhiza mungos Linn. Plant Cell Tiss Org 124:483-493

Ebrahimi M, Farajpour M, Hadavand H, Bahmani K, Khodaiyan F (2012) Essential oil variation among five Achillea millefolium ssp. elbursensis collected from different ecological regions of Iran. Ann Biol Res 3:3248-3253

Farajpour M, Ebrahimi M, Baghizadeh A, Aalifar M (2017) Phytochemical and Yield Variation among Iranian Achillea millefolium Accessions. HortScience 52:827-830

Farzaneh M, Ahmadzadeh M, Hadian J (2002) Chemical composition and antifungal activity of essential oils of three species of Tanacetum on some soil borne phytopathogens. Flav Frag J 17:150-152

Gabr AM, Ghareeb H, El Shabrawi HM, Smetanska I, Bekheet S (2016) Enhancement of silymarin and phenolic compound accumulation in tissue culture of Milk thistle using elicitor feeding and hairy root cultures. J Genet Eng Biotechnol 14:327-333

Gai Q-Y, Jiao J, Wang X, Zang Y-P, Niu L-L, Fu Y-J (2019) Elicitation of Isatis tinctoria $\mathrm{L}$. hairy root cultures by salicylic acid and methyl jasmonate for the enhanced production of pharmacologically active alkaloids and flavonoids. Plant Cell Tiss Org 137:77-86

Gupta S, Chaturvedi P (2019) Enhancing secondary metabolite production in medicinal plants using endophytic elicitors: a case study of Centella asiatica (Apiaceae) and asiaticoside. Endophytes for a Growing World, pp 310-323

Hao X, Shi M, Cui L, Xu C, Zhang Y, Kai G (2015) Effects of methyl jasmonate and salicylic acid on tanshinone production and biosynthetic gene expression in transgenic Salvia miltiorrhiza hairy roots. Biotechnol Appl Biochem 62:24-31

Heptinstall S, Awang D, Dawson B, Kindack D, Knight D, May J (1992) Parthenolide content and bioactivity of feverfew (Tanacetum parthenium (L.) Schultz-Bip.). Estimation of commercial and authenticated feverfew products. J Pharm Pharmacol 44:391-395

Huang C, Qian Z-G, Zhong J-J (2013) Enhancement of ginsenoside biosynthesis in cell cultures of Panax ginseng by $N, N^{\prime}$-dicyclohexylcarbodiimide elicitation. J Biotechnol 165:30-36

Jeong G-T, Park D-H, Ryu H-W, Hwang B, Woo J-C, Kim D, Kim S-W Production of antioxidant compounds by culture of Panax ginseng CA Meyer hairy roots. In: Twenty-sixth symposium on biotechnology for fuels and chemicals. 2005. Springer, Berlin. pp 1147-1157

Kastell A, Schreiner M, Knorr D, Ulrichs C, Mewis I (2018) Influence of nutrient supply and elicitors on glucosinolate production in E. sativa hairy root cultures. Plant Cell Tiss Org 132:561-572

Khan T, Abbasi BH, Khan MA (2018) The interplay between light, plant growth regulators and elicitors on growth and secondary metabolism in cell cultures of Fagonia indica. J Photochem Photobiol B: Biol 185:153-160

Krzyzanowska J, Czubacka A, Pecio L, Przybys M, Doroszewska T, Stochmal A, Oleszek W (2012) The effects of jasmonic acid and methyl jasmonate on rosmarinic acid production in Mentha $\times$ piperita cell suspension cultures. Plant Cell Tiss Org 108:73-81

Lee-Parsons CW, Ertürk S, Tengtrakool J (2004) Enhancement of ajmalicine production in Catharanthus roseus cell cultures with methyl jasmonate is dependent on timing and dosage of elicitation. Biotechnol Lett 26:1595-1599

Maggi F (2019) Feverfew (Tanacetum parthenium (L.) Sch. Bip.). Nonvitamin and nonmineral nutritional supplements. Elsevier, Amsterdam, pp $223-225$ 
Majdi M et al (2011) Biosynthesis and localization of parthenolide in glandular trichomes of feverfew (Tanacetum parthenium L. Schulz Bip.). Phytochemistry 72:1739-1750

Majdi M, Abdollahi MR, Maroufi A (2015) Parthenolide accumulation and expression of genes related to parthenolide biosynthesis affected by exogenous application of methyl jasmonate and salicylic acid in Tanacetum parthenium. Plant Cell Rep 34:1909-1918

Matkowski A (2008) Plant in vitro culture for the production of antioxidants-a review. Biotechnol Adv 26:548-560

Modarres M, Bahabadi SE, Yazdi MET (2018) Enhanced production of phenolic acids in cell suspension culture of Salvia leriifolia Benth. using growth regulators and sucrose. Cytotechnology 70:741-750

Murashige T, Skoog F (1962) A revised medium for rapid growth and bioassays with tobacco tissue cultures. Physiol Plant 15:473-497

Pourianezhad F, Tahmasebi S, Nikfar S, Mirhoseini M, Abdusi V (2016) Review on feverfew, a valuable medicinal plant. J Herb Med Pharmacol 5

Pourianezhad F, Rahnama H, Mousavi A, Khosrowshahli M, Mafakheri S (2019) Effects of combined elicitors on parthenolide production and expression of parthenolide synthase (TPPTS) in Tanacetum parthenium hairy root culture. Plant Biotechnol Rep 13:211-218

Qian Z-G, Zhao Z-J, Xu Y, Qian X, Zhong J-J (2006a) Novel synthetic 2,6-dichloroisonicotinate derivatives as effective elicitors for inducing the biosynthesis of plant secondary metabolites. Appl Microbiol Biotechnol 71:164-167

Qian ZG, Zhao ZJ, Xu Y, Qian X, Zhong JJ (2006b) Novel chemically synthesized salicylate derivative as an effective elicitor for inducing the biosynthesis of plant secondary metabolites. Biotechnol Prog 22:331-333

Rao SR, Ravishankar G (2002) Plant cell cultures: chemical factories of secondary metabolites. Biotechnol Adv 20:101-153

Sadat-Hosseini M, Farajpour M, Boroomand N, Solaimani-Sardou F (2017) Ethnopharmacological studies of indigenous medicinal plants in the south of Kerman, Iran. J Ethnopharmacol 199:194-204

Stojakowska A, Kisiel W (1997) Acetylenes in agrobacterium rhizogenes transformed root culture of Tanacetum parthenium. Pol J Chem 71:509-512

van Klink J, Becker H, Andersson S, Boland W (2003) Biosynthesis of anthecotuloide, an irregular sesquiterpene lactone from Anthemis cotula $\mathrm{L}$. (Asteraceae) via a non-farnesyl diphosphate route. Org Biomol Chem 1:1503-1508
Wang J, Qian J, Yao L, Lu Y (2015) Enhanced production of flavonoids by methyl jasmonate elicitation in cell suspension culture of Hypericum perforatum. Bioresour Bioprocess 2:5

Wang J, Li J, Wu X, Liu S, Li H, Gao W (2017) Assessment of genetic fidelity and composition: mixed elicitors enhance triterpenoid and flavonoid biosynthesis of Glycyrrhiza uralensis Fisch. tissue cultures. Biotechnol Appl Biochem 64:211-217

Wickens TD, Keppel G (2004) Design and analysis: a researcher's handbook. Upper Saddle River, Pearson Prentice-Hall

Yu Z-Z, Fu C-X, Han Y-S, Li Y-X, Zhao D-X (2006) Salicylic acid enhances jaceosidin and syringin production in cell cultures of Saussurea medusa. Biotechnol Lett 28:1027-1031

Yue W, Ming Q-I, Lin B, Rahman K, Zheng C-J, Han T, Qin L-p (2016) Medicinal plant cell suspension cultures: pharmaceutical applications and high-yielding strategies for the desired secondary metabolites. Crit Rev Biotechnol 36:215-232

Zhai X, Jia M, Chen L, Zheng C-j, Rahman K, Han T, Qin L-p (2017) The regulatory mechanism of fungal elicitor-induced secondary metabolite biosynthesis in medical plants. Crit Rev Microbiol 43:238-261

Zhang S, Ong C-N, Shen H-M (2004) Critical roles of intracellular thiols and calcium in parthenolide-induced apoptosis in human colorectal cancer cells. Cancer Lett 208:143-153

Zhao J, Zhu W-H, Hu Q (2001) Enhanced catharanthine production in Catharanthus roseus cell cultures by combined elicitor treatment in shake flasks and bioreactors. Enzyme Microb Technol 28:673-681

Zhao J, Davis LC, Verpoorte R (2005) Elicitor signal transduction leading to production of plant secondary metabolites. Biotechnol Adv 23:283-333

Zhong J-J (2001) Biochemical engineering of the production of plant-specific secondary metabolites by cell suspension cultures. In: Plant cells. Springer, Berlin. pp 1-26

\section{Publisher's Note}

Springer Nature remains neutral with regard to jurisdictional claims in published maps and institutional affiliations.

\section{Submit your manuscript to a SpringerOpen ${ }^{\circ}$ journal and benefit from:}

- Convenient online submission

- Rigorous peer review

- Open access: articles freely available online

- High visibility within the field

- Retaining the copyright to your article

Submit your next manuscript at springeropen.com 